\title{
Utilization of Marine Fishery Wastes for Protease Production by Halophilic Bacterium Halolactibacillus Miurensis RSK CAS7- A Microbial Approach
}

\author{
Sathishkumar R. ${ }^{1,2 *}$, Ananthan G. ${ }^{1}$, Anand M. ${ }^{2}$, Sobana S.S. ${ }^{2}$, Ibrahim M. ${ }^{2}$ \\ ${ }^{1}$ Centre of Advanced Study in Marine Biology, Faculty of Marine Sciences, \\ Annamalai University, India \\ ${ }^{2}$ Syed Hameedha Arts \& Science College, Tamil Nadu, India \\ *sathishkumarmicro@gmail.com
}

\begin{abstract}
The marine wastes generates $50-60 \%$ of the total weight of shell fish as waste consists of protein (35-50\%), chitin (15-25\% of dry weight) which considered as major environmental pollutants due to uncontrolled dumping. The utilisation of marine waste not only solves environmental problems but also decreases the production costs of microbial products. So far in this study, halophilic bacterium was isolated from marine ascidians and identified as Halolactibacillus miurensis RSK CAS7 through 16S rRNA sequence. The effect of different marine wastes such as shrimp shell powder (SSP), crab shell powder (CSP), squid pen powder (SPP), sardinella powder, tuna powder and anchovy powder were tested on protease production. Among these Sardinella powder $(579.46 \mathrm{U} / \mathrm{ml})$ and shrimp shell powder (470.36 $\mathrm{U} / \mathrm{ml}$ ) showed maximum level of protease production and followed by other marine wastes. All the significant nutrients identified from the preliminary screening were further screened by using Plackett - Burman Design and it resulted sardinella powder, $\mathrm{K}_{2} \mathrm{HPO}_{4}, \mathrm{NaCl}$ and $\mathrm{pH}$ were the highly influencing factors and their concentration were further optimized by using central composite design. Central composite design revealed that four independent variables such as Sardinella powder (14.21 g/l), $\mathrm{K}_{2} \mathrm{HPO}_{4}(3.81 \mathrm{~g} / \mathrm{l}), \mathrm{NaCl}(154.1 \mathrm{~g} / \mathrm{l})$ and $\mathrm{pH}(9.0)$ were significantly influenced the protease production. With these optimum concentration levels, the maximum protease production $(1,794.41 \mathrm{U} / \mathrm{ml})$ was observed. Thus, protease production by microbial conversion of marine wastes suggested its potential utilisation for the production of high value products.
\end{abstract}

Keywords: Waste Management, Protease, Marine Wastes, Halophilic Bacteria

Proceedings of the $22^{\text {nd }}$ International Forestry and Environment Symposium 2017 of the Department of Forestry and Environmental Science, University of Sri Jayewardenepura, Sri Lanka 